\title{
A Case Study on Popular Science Education: Mobile Green Energy Castle into Countryside
}

\author{
Meng-Fen Shih ${ }^{a}$, Chyi-How Lay ${ }^{b, c, d, ~}{ }^{*}$ Hoang-Jyh Leu ${ }^{b, c, d,}$, Chin-Choa Chen ${ }^{e,}$ \\ Chiu-Yue Lin $^{a, c, d}$ \\ ${ }^{a}$ Dept of Environmental Engineering and Science, Feng Chia University, Taiwan \\ ${ }^{\mathrm{b}}$ General Education Center, Feng Chia University, Taiwan \\ ${ }^{\mathrm{c}}$ Green Energy Development Center, Feng Chia University, Taiwan \\ ${ }^{\mathrm{d}}$ Master's Program of Green Energy Science and Technology, Feng Chia University, Taiwan \\ ${ }^{\mathrm{e}}$ Dept. of Landscape Architecture, Chung Chou University of Science and Technology, \\ Taiwan \\ *Corresponding author: Chyi-How Lay, Ph D, kfc0612@gmail.com
}

\begin{abstract}
Green renewable energy is now the focus of global attention and a key opportunity for non-oilexporting countries to take ownership of their energy. The study integrated the green energy technologies such as solar, biomass, wind, fuel cell bike and carbon footprint to form the experience activities such as "green energy product", "green energy aids" and "interactive game" in a "Green Moving Castle" and moved into the elementary and junior high schools in remote villages and towns to share the green energy scientific knowledge. The activity shared the knowledge with attendance of 1866 and the travel distance of $3399 \mathrm{~km}$.
\end{abstract}

Key words: Green energy; science in the countryside; green energy products; green energy DIY; interactive tool

\section{Introduction}

In recent years, the problem of global warming has become more and more serious. The greenhouse effect caused by the massive emission of greenhouse gases which by the extensive use of fossil fuels has seriously impacted the environment and caused global climate variability. ${ }^{1}$ With the development of human science and technology, the demand for human reliance on energy has risen sharply since the Industrial Revolution. Among them, the fossil oil and coal fossils are the most mainly energy sources for human beings. In the period, the global demand for fossil fuels increased significantly, coupled with artificial speculation and other factors, the international fossil fuel prices has a dramatic effect in 2008 that caused by global inflation and rising price index and influence people's livelihood economy suffered seriously. Therefore, the world began to actively develop environmentally friendly green energy, in order to reduce dependence on fossil fuels. ${ }^{2,3}$

In the past, oil and energy were in the hands of a handful of powerful countries in the world, and these powers also held the world's technological and economic development. Green renewable energy is now the focus of global attention and a key opportunity for non-oilexporting countries to take ownership of their energy. The development of green energy technology is a cross-border knowledge, not only related to the resources, but also need policy, education, science and technology and the national people's recognition and support. 
Feng Chia University has a long-term committed to green energy technology industry talent cultivation program, and set up green energy science and technology master degree courses in 2009, and the creation of green energy science and technology courses as the university elective courses. Green Energy Development Center (GEDC) at Feng Chia University has a professional field of teachers and the world's leading anaerobic biological hydrogen production technology. GEDC has integrated popular science materials to continuously expand the popularization of green energy knowledge and enhance the popular knowledge of Taiwan's society and indirectly strengthen Taiwan's scientific and technological foundation.

This research integrates the green energy popularization theme of solar energy, biomass energy, wind energy, carbon footprint and green electric bicycles bicycle developed by GEDC. Through the planning of green energy products experience, green energy and teaching experience and interactive game experience and other popular science activities, innovative green energy technology, innovative methods into a simple, easy to understand, you can directly operate the Popular Textbooks and Teaching Aids. These science teaching materials and teaching aids will be installed in the mobile "green moving castle" vehicles, traveling to remote high schools and primary schools in villages and towns in Taiwan, and to share green energy science knowledge with students and teachers. And also to train university students to form a volunteer team, to provide professional and technical training courses and professional training, training and learning with the concept of science volunteer volunteers.

The final goal is to promote green energy through popularization of popular science knowledge, as well as green energy science popularization of the teaching and training, to help people living in remote areas, and even the people of the country can understand green energy. At the same time, but also to help people agree with the country's renewable energy development policies, and to develop energy conservation to reduce carbon emissions, the concept of sustainability.

\section{Experiments}

\subsection{Activity theme}

The content of activity is as shown in Table 1. It includes (1) green energy products experience, (2) green teaching aids experience (hands-on science), and (3) interactive game experience three sub-items. Each sub-item has 2 to 4 sub-activities, each sub-activity time has 10 to 90 minutes. The activities are described below.

\subsubsection{Solar energy and wind energy charge and discharge teaching aids}

The teaching aids is the original teaching equipment from Green Energy Development Center of Feng Chia University. It consists of "Handheld Charge / Discharge Operation Box", "Solar Panel" and "Wind Turbine". Hand-held system has the advantages of easy to carry, allowing students to simple operation, direct observation of solar power and wind power status.

\subsubsection{Green electric bicycles}

Green electric bicycle equipped with energy storage system, with power management system, through the solar cell charging. The way to conduct the activity is to explain the structure of the electric bike and the environmental benefits first, and then to experience the convenience of this bike. 


\subsubsection{Gaseous biomass energy production}

The operation of the experimental part of the applicant to design and development of biomass-based teaching aids mainly. The glass tube was used to simulate the bio-fermentation tank, sucrose and enzyme as the raw material source and the biomass energy strain respectively. The generation of the gaseous biomass energy was observed from the biogas accumulated in the balloon over a period of 5 to 10 minutes.

Table 1 - Green energy science popularization content

\begin{tabular}{|c|c|c|c|}
\hline & Item name & Event name & Teaching time (min) \\
\hline & \multirow{2}{*}{$\begin{array}{l}\text { Green energy } \\
\text { products } \\
\text { experience }\end{array}$} & $\begin{array}{l}\text { A1. "Solar and wind energy charge and } \\
\text { discharge teaching aids" experience }\end{array}$ & 30 \\
\hline & & A2. "Green electric bicycle" experience & 30 \\
\hline \multirow{4}{*}{$(2)$} & \multirow{4}{*}{$\begin{array}{l}\text { Green energy } \\
\text { teaching aids } \\
\text { experience }\end{array}$} & B1. Gaseous biomass energy production & 60 \\
\hline & & $\begin{array}{l}\text { B2. Production of Liquid Bio - energy from } \\
\text { Waste Edible Oil }\end{array}$ & 90 \\
\hline & & B3. Micro-solar cell production & 60 \\
\hline & & B4. Micro-wind turbine production & 60 \\
\hline & \multirow{2}{*}{$\begin{array}{l}\text { Interactive } \\
\text { gaming } \\
\text { experience }\end{array}$} & C1. Green energy science introduction & 50 \\
\hline & & C2. Science cartoon appreciation & 10 \\
\hline
\end{tabular}

\subsubsection{Production of Liquid Bio - energy from Waste Edible Oil}

The purpose of the course is to introduce the production technology of various liquid bioenergy, and to convert waste oil into biodiesel and to provide it as fuel oil. And in the actual operation of waste oil by transesterification process to generate bio-diesel and crude glycerol process, so that students understand the liquid bio-energy can often use the purification process and related applications.

\subsubsection{Micro-solar cell production}

Practical part of the operation is to allow students to use conductive glass, dyes, electrolytes, titanium dioxide production of the main battery, and then conductive tape as the electrode made of solar cells, and three meters with electricity generation efficiency measurement comparison.

\subsubsection{Micro-wind turbine production}

The purpose of the "Micro Wind Turbine Production" course is to understand the principles of wind power generation and to understand the relationship between the wind power and the size of electricity generated by wind turbines. The briefing will introduce the structure of the wind turbine and the development of the wind turbine at home and abroad, and then use the prize to increase the interaction. Part of the planning is to allow students for personally produce small wind turbines by observe the different types of wind turbine blades or strength to observe the differences in power generation efficiency. 


\subsubsection{Green energy science introduction}

The "Green Energy Science Introduction" is a briefing presentation on climate change, the greenhouse effect, energy structure, renewable energy development, renewable energy applications and hydrogen energy vehicles, etc. In a simple and lively graphical content to help students understand the knowledge of green energy within 50 minutes.

\subsubsection{Green energy carton}

"Bio-Stars War" was the carton that produced by Green Energy Development Center of Feng-Chia University. This film is telling a story about bioenergy technology. Two cartoon characters, named $\mathrm{H}_{2}$ and $\mathrm{CH}_{4}$, were created for hydrogen producer and methane producer respectively. The "Bio-Stars War" is shown as following website https://vimeo.com/103501112.

\subsection{Assessment tool}

A questionnaire is divided into two parts. The first part is the basic information, including gender, age, the highest academic qualifications, and expert area. The second part has 10 questions. These questions were created by a committee and judged based on the correctness, applicability, necessity and coverage of the theme. The committee members were from high school teachers and professors. The questionnaire should include the following expert area: "Gaseous Bioenergy", "Liquid Bioenergy", "Solar Energy", "Wind Energy", "Energy Storage" and "Energy Conservation".

\section{Results and discussions}

\subsection{Circuit activity}

"Mobile Green Energy Castle" toured the primary and secondary schools in remote villages and towns in Taiwan to share the green energy knowledge with students and teachers. The volunteers in "Mobile Green Energy Castle" also looked forward to the move while they were sharing the green energy knowledge. In this one year's event, there were 18 circuit activities during September 2015 to May 2016. The total number of participant person-time was student: 1,866, proffers: 22 and volunteer: 86. The circuit distance was 3,399 km.

\subsection{Questionnaire Assessment}

\subsubsection{Participant background}

Statistics show that the number of primary schools is large but the number of students is small. This is mainly due to the long-term transfer of the population between urban and rural and the influence of the minority population, and the discrepancy between the number of available students in urban and rural areas has gradually become apparent. The high number of schools because of the small number of campus location is located in accordance with the specific school district construction, so the number of students concentrated, making the statistics for the highest number of high school students. The number of junior high schools and the number of students are equally distributed, but also echo this phenomenon (Fig. 1). There was no significant difference in the gender ratio between the two genders (Fig. 2). 

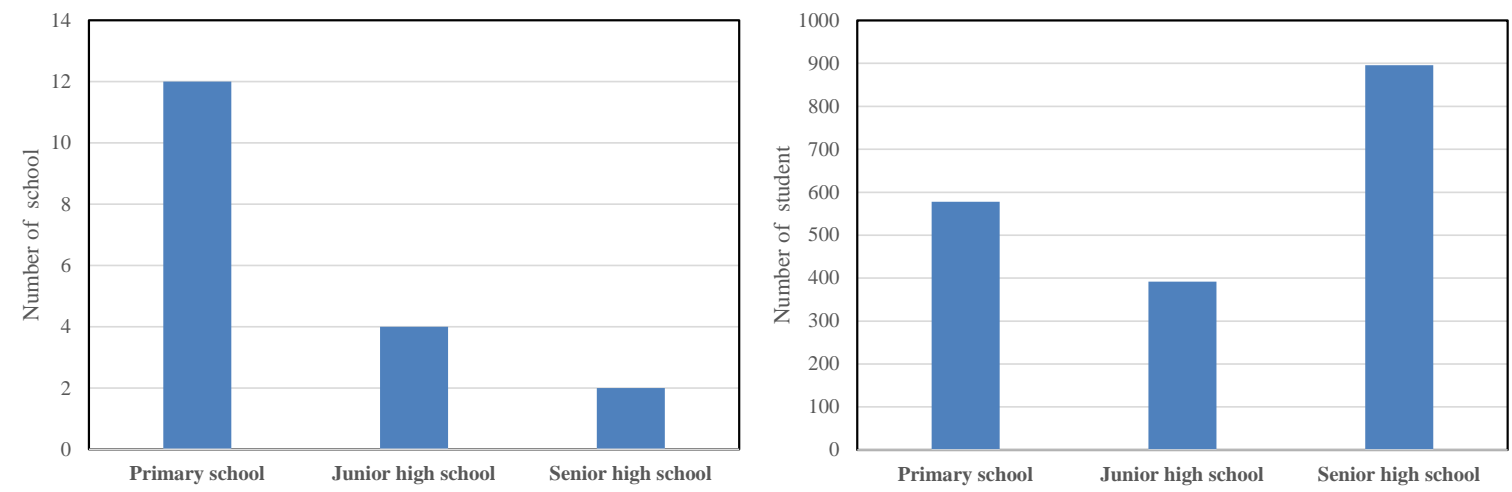

Fig. 1 Number of school and student
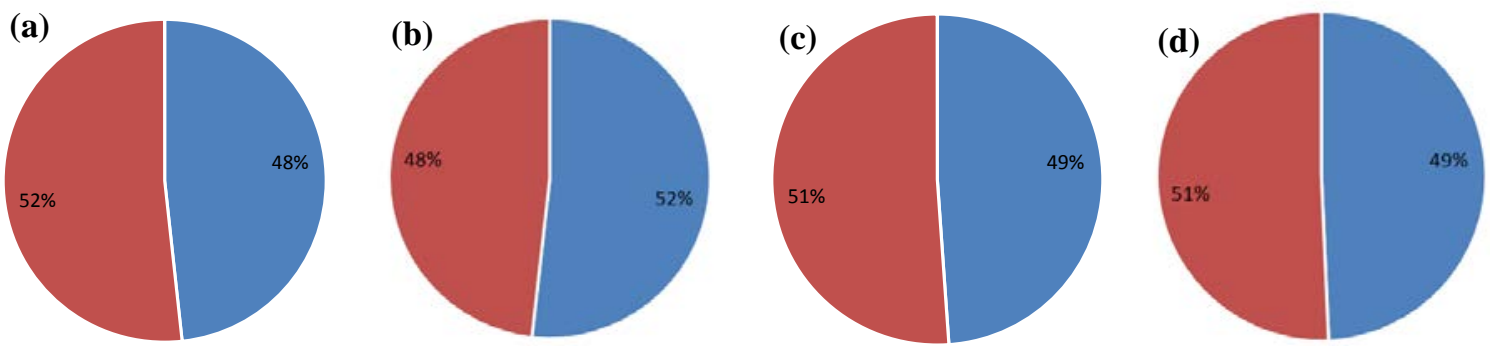

Fig. 2 Gender ratio of students (a) primary school (b) junior high school (c) senior high school (d) overall

\subsubsection{Project result}

After the implementation of this project, the results can be found from the statistics, students receive the same subjects in the subjects of science test scores improved significantly, and the distribution of an average between the averages. (Fig. 3)

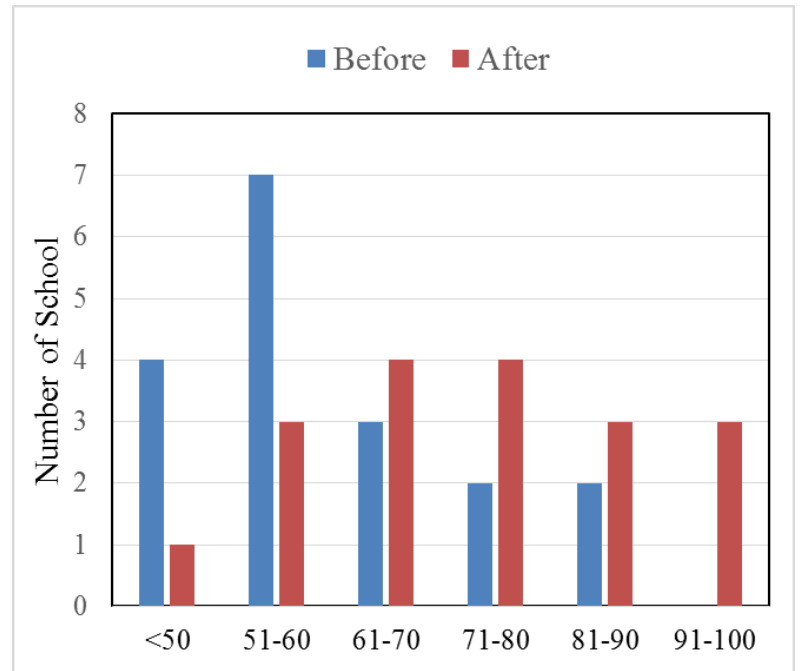

Fig. 3 Correct answer percentage of schools which before and after accepting the project (\%)

The gap between the urban and rural students' knowledge and practice of popular science has been observed from the results also narrowed. (Table 2) 
Table 2 - Promotion result of the circuit activity of "Mobile Green Energy Castle"

\begin{tabular}{|c|c|c|c|}
\hline $\begin{array}{c}\text { Runed distance } \\
(\mathrm{km})\end{array}$ & $\begin{array}{c}\text { Average before the test } \\
(\%)\end{array}$ & $\begin{array}{c}\text { Average after the test } \\
(\%)\end{array}$ & $\begin{array}{c}\text { Average Promotion } \\
(\%)\end{array}$ \\
\hline 3,399 & 60.0 & 73.2 & 13.2 \\
\hline
\end{tabular}

Science knowledge is closely related with each individual's life knowledge, in terms of practice, but also suitable for use in the life of the actual technology. It has been a continuing need and issue for improvement of the gap between urban and rural areas that includes population, school distribution and resource allocation. Through the implementation of the research results, we use mobile teaching methods to shorten the gap between urban and rural teaching resources.

\section{Conclusion}

From the results inference, through the theory and practice of teaching methods, allowing students to be more easily absorbed by the content of popular science teaching, the content of the content and the practical application of complementary effects, which from the promotion activity before and after the average score It can be observed that after the implementation of the promotion activity, the overall average scores of all the schools have been improved, and the gaps in teaching resources between urban and rural areas have been shortened through the mobile teaching. Through the theory and practice of teaching content, it is to strengthen the combination of learning and life to achieve the true purpose of education, but also the proper use of resources.

\section{Acknowledgements}

The authors gratefully acknowledge the financial supports of Ministry of Science and Technology (MOST 104-2515-S-035-001, 105-2511-S-035-004) and Feng Chia University, Taiwan.

\section{References}

1. G. Kumar, A. Mudhoo, P. Sivagurunathan, D. Nagarajan, A. Ghimre, C.H. Lay, C.Y. Lin, D.J. Lee, J.S. Chang, Recent insights in the cell immobilization technology applied for dark fermentative hydrogen production. Bioresourc. Technol. 219 (2016) 725-737.

2. B. Sen, J. Aravind, P. Kanmani, C.H. Lay, State of the art and future concept of food waste fermentation to bioenergy. Renew. Sust. Energ. Rev. 53 (2016) 547-557.

3. C.Y. Lin, C.H. Lay, B. Sen, C.Y. Chu, G. Kumar, C.C. Chen, J.S. Chang, Fermentative hydrogen production from wastewaters: a review and prognosis. Int. J. Hydrogen Energy 37 (2012) 15632-15642. 